\title{
Experimental investigations on the effect of addition of Ag into ternary lead free solder alloy $\mathrm{Sn}-\mathbf{1 C u}-\mathbf{1 N i}$
}

\author{
$\mathrm{S} \mathrm{Jayesh}^{\dagger}$, J. Elias \\ †jayesh.jhe@gmail.com
}

Department of Mechanical Engineering, School of Engineering, Cochin university of Science and Technology, 682022, Kochi, Kerala, India

Lead cannot be used in solder alloys due to its deep-rooted toxicity. In the view of this fact, much legislation came into existence to prohibit the usage of lead in solder joints. Many lead free solder alloys came to replace the conventional Sn-Pb solder alloy. This study investigates the effect of addition of $\mathrm{Ag}(0.25,0.5,0.75,1 \mathrm{wt} . \%)$ on the melting behavior, wetting characteristics, hardness and microstructure properties of ternary lead free solder alloy - Sn-1Cu-1Ni. Melting temperature is found to be decreased slightly from $232.2^{\circ} \mathrm{C}$ to $228.7^{\circ} \mathrm{C}$. The distance between the adjacent atoms and the root mean vibration amplitude determines the melting temperature property. $\mathrm{Ag}_{3} \mathrm{Sn}$ formed in the matrix has changed the melting point characteristics which resulted in the slight decrease of the melting temperature. Contact angle get reduced from $36.75^{\circ}$ to $22.87^{\circ}$. Hardness value is found to be increased from 16.1 to 19.2 . Ag is found to be uniformly distributed in the microstructure analysis. As far as the data available show, the microstructure of this lead free solder alloy consists of coarse $\beta$-Sn grains. $\mathrm{Ag}_{3} \mathrm{Sn}, \mathrm{Cu}_{6} \mathrm{Sn} \mathrm{n}_{5}$ and tin in the alloys are found in the eutectic region. The refinement of $\beta$-Sn grains is happened in a good manner due to the addition of particle of $\mathrm{Ag}$. The recommended amount of $\mathrm{Ag}$ addition in to the $\mathrm{Sn}-1 \mathrm{Cu}-1 \mathrm{Ni}$ is $1 \mathrm{wt}$.\%. This lead free alloy can be used in electronic packages exposed to relatively high temperatures.

Keywords: lead-free, solder alloy, melting temperature, hardness, microstructure.

УДК: 539.21

\section{Экспериментальное исследование влияния добавки $\mathrm{Ag}$ в тройной бессвинцовый сплав для пайки $\mathrm{Sn}-1 \mathrm{Cu}-1 \mathrm{Ni}$}

\author{
Джаиш $\mathrm{C}^{\dagger}$, Элиас Дж. \\ Департамент инженерной механики, Инженерная школа, Кошинский университет науки и технологий, 682022 , \\ Кошин, Керала, Индия
}

Свинец не может быть использован в сплавах для пайки из-за сильной токсичности. Ввиду этого, было принято много законодательных актов о запрете использования свинца в припоях. Взамен обычного сплава для пайки $\mathrm{Sn}-\mathrm{Pb}$ было предложено множество бессвинцовых припоев. В данной работе исследуется влияние добавки Аg (в количестве 0.25, 0.5, 0.75, 1 вес.\% ) на температуру плавления, характеристики смачиваемости, твердость и микроструктурные свойства тройного бессвинцового сплава для пайки $\mathrm{Sn}-1 \mathrm{Cu}-1 \mathrm{Ni}$. Обнаружено некоторое снижение температуры плавления от $232.2^{\circ} \mathrm{C}$ до $228.7^{\circ} \mathrm{C}$. Температура плавления определяется расстоянием между соседними атомами и среднеквадратичным отклонением амплитуд их колебаний. Соединение $\mathrm{Ag}_{3} \mathrm{Sn}$, образующееся в матрице, изменяет поведение вблизи точки плавления, что приводят к снижению температуры плавления. Контактный угол уменьшается с $36.75^{\circ}$ до $22.87^{\circ}$. Твердость повышается с 16.1 до 19.2. Микроструктурный анализ показывает, что серебро распределено в материале однородно. Как показывают имеющиеся данные, микроструктура этого бессвинцового сплава состоит из крупных зерен $\beta$-Sn. В эвтектической области сплавов обнаруживаются Ag $\mathrm{Sn}_{3}$ $\mathrm{Cu}_{6} \mathrm{Sn}_{5}$ и олово. Благодаря добавке Ag происходит измельчение зерен $\beta-\mathrm{Sn}$. Рекомендуемое количество добавок $\mathrm{Ag}$ в сплав $\mathrm{Sn}-1 \mathrm{Cu}-1 \mathrm{Ni}$ составляет 1вес.\%. Этот бессвинцовый сплав для пайки может быть использован в электронных блоках, эксплуатируемых при достаточно высоких температурах.

Ключевые слова: бессвинцовый, сплав для пайки, температура плавления, твердость, микроструктура. 


\section{Introduction}

For the last two decades solder alloys are having revolutionary changes because of the ban on lead in the alloy citing its inherent toxicity and environment issues. Strict government regulations and the demand from customers forced the advanced electronic package industries to progressively increase the usage of lead free solder alloys. $[1,2,12]$. The commonly used $\mathrm{Sn}-\mathrm{Pb}$ alloy is therefore replaced by a large number of lead free alloy groups. As a replacement for the $\mathrm{Sn}-\mathrm{Pb}$ alloy, following alloys are mainly used: $\mathrm{Sn}-\mathrm{Zn}, \mathrm{Sn}-\mathrm{Cu}$, $\mathrm{Sn}-\mathrm{Bi}, \mathrm{Sn}-\mathrm{Bi}-\mathrm{Ag}, \mathrm{Sn}-\mathrm{Ag}-\mathrm{Cu}, \mathrm{Sn}-\mathrm{Zn}-\mathrm{Bi}$ etc. [3-11]. Melting point, hardness, wetting property and the microhardness are the important properties that should be considered while selecting an alternate for the $\mathrm{Sn}-\mathrm{Pb}$ alloy [13-16]. $\mathrm{Sn}-\mathrm{Cu}$ received much attention as a lead free solder alloy choice when cost is considered as a variable. But $\mathrm{Sn}-\mathrm{Cu}$ alloy is having inferior wetting characteristics and mechanical properties. [16-19]. The microstructural and mechanical properties of the lead free solder alloys can be improved substantially by the addition of foreign materials. The addition of $\mathrm{Ni}$ into the $\mathrm{Sn}-\mathrm{Cu}$ enhances the properties of the solder alloy $[20,21]$. In this study, analysis is done on the perspective of the addition of $\mathrm{Ag}$ in to the ternary $\mathrm{Sn}-1 \mathrm{Cu}-1 \mathrm{Ni}$ alloy. The $\mathrm{Ag}$ is added in $0.25,0.5,0.75$ and $1 \mathrm{wt} . \%$ into the solder alloy matrix of $\mathrm{Sn}-1 \mathrm{Cu}-1 \mathrm{Ni}$. Hardness, melting temperature, contact angle and the microstructure of these five alloys (one sample of $\mathrm{Sn}-\mathrm{Cu}-\mathrm{Ni}$ and four samples of $\mathrm{Sn}-\mathrm{Cu}-\mathrm{Ni}-x \mathrm{Ag}$ ) were analyzed. The amount of silver should be very carefully determined because of the fact that the silver will increase the cost of the solder alloy drastically.

\section{Experimental procedure}

\subsection{Sample preparation}

The most commonly followed method for the preparation of the solder alloys is powder metallurgy. The elements in the composition will be in the form of powder. This powder will be compacted as a green body. This is then sintered into the required shape at enhanced temperatures. $\mathrm{Sn}, \mathrm{Cu}$, $\mathrm{Ni}$ and $\mathrm{Ag}$ were made available in the form of powder and are allowed to melt at enhanced temperature of about $900^{\circ} \mathrm{C}$ for 45 minutes. This molten material is then transferred into specially designed cylindrical molds. All these five alloys with variation in the composition of $\mathrm{Ag}$ is allowed to quench and were kept in the room temperature for 2 days. Visual analysis of these alloys was conducted for the initial acceptance. These alloys were undergone chemical composition analysis.

\subsection{Melting temperature analysis}

Higher melting temperature of the solder alloy is considered as a bad property citing the fact that the electronic package will fail at higher temperatures. Melting temperature analysis of all the five samples were conducted using Thermo Gravimetric and Differential Thermal analysis (TG-DTA). Thermo Gravimetric analysis (TGA) measured the weight loss or gain as a function of temperature, the TGA trace appear as steps, it can be deal with the derivative of TGA with respect to time or temperature. Differential thermal analysis (DTA) is a technique for recording the difference in temperature between a substance and a reference material as a function of time or temperature as the two specimens are subjected to identical temperature regimes in an environment heated or cooled at a controlled rate.

\subsection{Microhardness measurement and wetting analysis}

Abrasion and wear characteristics of a material can be assessed using hardness analysis. Hardness tests were performed using hardness testing machine. Each $\mathrm{HV}$ value was the average of fifteen different readings which were noted down at random points on the surface of the sample. Sample preparation was done using grinding by taking different grades of $\mathrm{SiC}$ papers. Then the samples were polished. The surfaces of the alloys were analyzed in Axio Vertical A1 metallurgical microscope before and after the microhardness test.

Wetting can defined as the ability of the molten solder alloy to react with the bottom substrate. Intermetallic compounds (IMC) will be formed which acts as the adhesion layer to join the solder and the substrate. The molten sample of the five alloys was spread over the $\mathrm{Cu}$ substrate. Then the contact angle is measured. Generally if the wetting or contact angle lies between $0^{\circ}$ and $90^{\circ}$ the system is said to be wet. If the wetting or contact angle is between $90^{\circ}$ and $180^{\circ}$ the system is considered to be non-wetting.

\subsection{Microstructure analysis}

Four grades of $\mathrm{SiC}$ papers were used for grinding the five alloy samples which is followed by the mechanical polishing with a diamond suspension. 95\% ethanol solution/5\% $\mathrm{HCl}$ is used for chemical etching. The surface details of the samples were analyzed by field-emission scanning electron microscopy (FE-SEM, Carl Zeiss Sigma). All the images were taken at a magnification of $5.00 \mathrm{KX}$, scale $=1 \mu \mathrm{m}$, Electron High Tension $(\mathrm{EHT})=5.00 \mathrm{Kv}$, Working Distance $(\mathrm{WD})=3.2 \mathrm{~mm}$

\section{Result and Discussion}

\subsection{Chemical Composition}

Five alloy samples were made with different composition. Chemical compositions of the alloys were analyzed using ICP-OES. The results of the analysis are shown in the Table 1.

\subsection{Melting Temperature}

The melting points of all the five samples were tested using TGA analysis. The results were noted down and a comparison is shown in the Fig. 1. It can be seen that the melting temperature of $\mathrm{Sn}-\mathrm{Cu}-\mathrm{Ni}$ alloy is $232.2^{\circ} \mathrm{C}$. The melting temperature of $\mathrm{Sn}-\mathrm{Cu}-\mathrm{Ni}-x \mathrm{Ag}(x=0.25,0.5$, $0.75,1$ wt.\%) are $231.2,230.1,229.4,228.7$ respectively. So it can be concluded that with the addition of Ag into $\mathrm{Sn}-\mathrm{Cu}-\mathrm{Ni}$, the melting temperature is decreasing slightly. The distance between the adjacent atoms and the root mean vibration amplitude determines the melting temperature property. 
Table 1. Chemical composition required (\%) and the composition results (\%).

\begin{tabular}{|c|c|c|c|c|c|c|c|c|}
\hline \multirow{2}{*}{ Solder Alloy } & \multicolumn{3}{|c|}{ Composition required (wt.\%) } & \multicolumn{4}{c|}{ Chemical Composition results (wt.\%) } \\
\cline { 2 - 9 } & $\mathrm{Sn}$ & $\mathrm{Cu}$ & $\mathrm{Ni}$ & $\mathrm{Ag}$ & $\mathrm{Sn}$ & $\mathrm{Cu}$ & $\mathrm{Ni}$ & $\mathrm{Ag}$ \\
\hline Sn-0.5Cu-1Ni & 98.5 & 1 & 1 & 0 & 98.4833 & 1.0180 & 0.9987 & 0 \\
\hline Sn-0.5Cu-1Ni-0.25Ag & 98.25 & 1 & 1 & 0.25 & 98.2234 & 0.9987 & 1.0456 & 0.2321 \\
\hline Sn-0.5Cu-1Ni-0.5Ag & 98 & 1 & 1 & 0.5 & 98.0734 & 1.0534 & 0.9875 & 0.4857 \\
\hline Sn-0.5Cu-1Nii-0.75Ag & 97.75 & 1 & 1 & 0.75 & 97.7545 & 1.0134 & 0.9523 & 0.7798 \\
\hline Sn-0.5Cu-1Ni-1Ag & 97.5 & 1 & 1 & 1 & 97.4845 & 0.9895 & 0.9675 & 1.0580 \\
\hline
\end{tabular}

$\mathrm{Ag}_{3} \mathrm{Sn}$ formed in the matrix has changed the melting point characteristics which resulted in the slight decrease of the melting temperature. The undercooling of $\mathrm{Sn}-\mathrm{Cu}-\mathrm{Ni}$ solder material is found to be decreasing slightly with the addition of Ag.

\subsection{Hardness and Wetting}

Contact angle as a function of $\mathrm{Ag}$ addition to the $\mathrm{Sn}-\mathrm{Cu}-\mathrm{Ni}$ solder is shown in the Fig. 1. It can be seen that the contact angle of $\mathrm{Sn}-\mathrm{Cu}-\mathrm{Ni}$ alloy is $36.75^{\circ}$. The contact angle of Sn-Cu-Ni- $x$ Ag $(x=0.25,0.5,0.75,1$ wt. $\%)$ are $27.54^{\circ}, 26.44^{\circ}$, $24.12^{\circ}$ and $22.87^{\circ}$ respectively. Therefore, the contact angle is getting reduced as the $\mathrm{Ag}$ is added.

It can be found that the hardness value increases as the amount of $\mathrm{Ag}$ is increased in the $\mathrm{Sn}-\mathrm{Cu}-\mathrm{Ni}$ alloy. The hardness value of $\mathrm{Sn}-\mathrm{Cu}-\mathrm{Ni}$ alloy is found to be $16.1 \mathrm{HV}$, and when $1 \%$ of $\mathrm{Ag}$ is added to this alloy, hardness value is found to be increased to $19.2 \mathrm{HV}$. A comparison of microhardness value of these five alloys with SAC305 and SAC405 were also conducted. The microhardness property values of SAC305 and SAC 405 were taken as $13.47 \mathrm{HV}$ and $13.98 \mathrm{HV}$.

Comparison of variation of melting temperature, contact angle and hardness of the alloy with percentage of Ag addition are shown in Figs. 1, 2 and 3.

\subsection{Microstructure analysis}

As far as the data available show, the microstructure of this lead free solder alloy consists of coarse $\beta$-Sn grains. $\mathrm{Ag}_{3} \mathrm{Sn}, \mathrm{Cu}_{6} \mathrm{Sn}_{5}$ and tin in the alloys are found in the eutectic region. The refinement of $\beta$-Sn grains is happened in a good manner due to the addition of particle of Ag. Ag is found to be uniformly distributed on the solder matrix which can be observed from the microstructure analysis. Eutectic bands are found to be becoming narrow. The refined grain boundary is the reason for the slipping of the dislocation prevention. Another reason is the $\mathrm{Cu}_{6} \mathrm{Sn}_{5}$ dispersion at the grain boundary of $\beta$-Sn dendrites in a uniform fashion. Evaluation also revealed the $\alpha$-phase $\mathrm{Cu}$ and $\beta$-phase Ag. The FE-SEM image of $\mathrm{Sn}-\mathrm{Cu}-\mathrm{Ni}$ when 1 wt.\% Ag added is shown in the Fig. 4.

\section{Conclusion}

The mechanical and microstructure analysis of the effect of addition of Ag particles into the lead free solder ternary alloy $\mathrm{Sn}-1 \mathrm{Cu}-1 \mathrm{Ni}$ has been done. The Ag addition resulted in the slight decrease in the melting temperature. $\mathrm{Ag}_{3} \mathrm{Sn}$ formed in the matrix have resulted in the slight decrease in the melting temperature. The microhardness of the alloys were found to

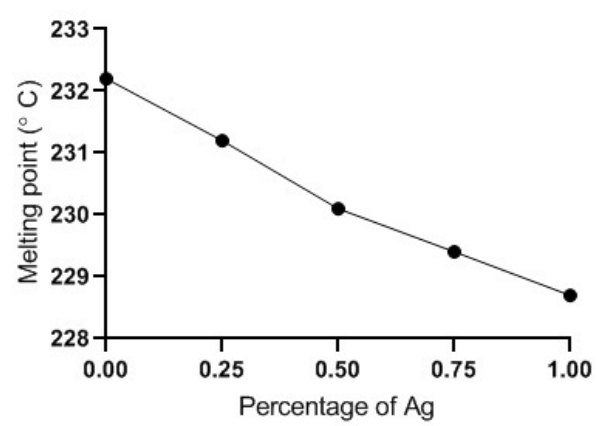

Fig. 1. Variation of Melting temperature.

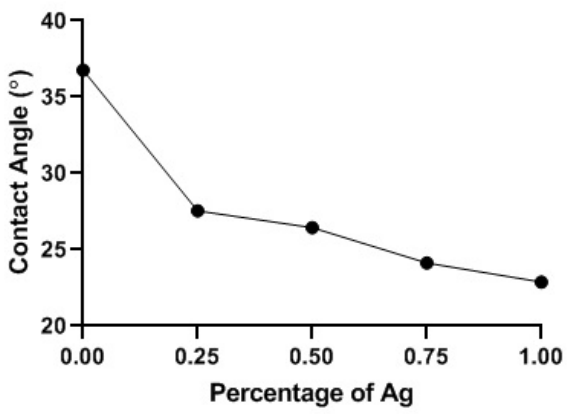

Fig. 2. Variation of Contact angle.

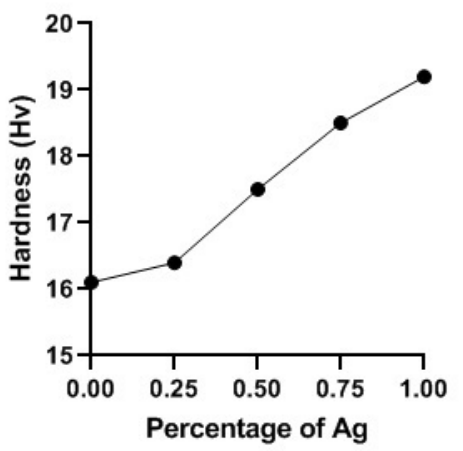

Fig. 3. Variation of Hardness.

be increasing with the addition of the Ag. The prevention of sliding and the holding of the grain boundaries due to the presence of $\mathrm{Ag}$ in the solder matrix strengthens the microhardness of the alloy. When commenting about the wetting characteristics, a significant improvement is observed in the contact angle. The microstructure observations revealed that the Ag was uniformly distributed on the surface of the solder matrix. The recommended content of the Ag to be added into the $\mathrm{Sn}-1 \mathrm{Cu}-1 \mathrm{Ni}$ solder alloy is $1 \mathrm{wt} . \%$. It can be used in the electronic packages in the automobiles where the temperature is relatively high. 


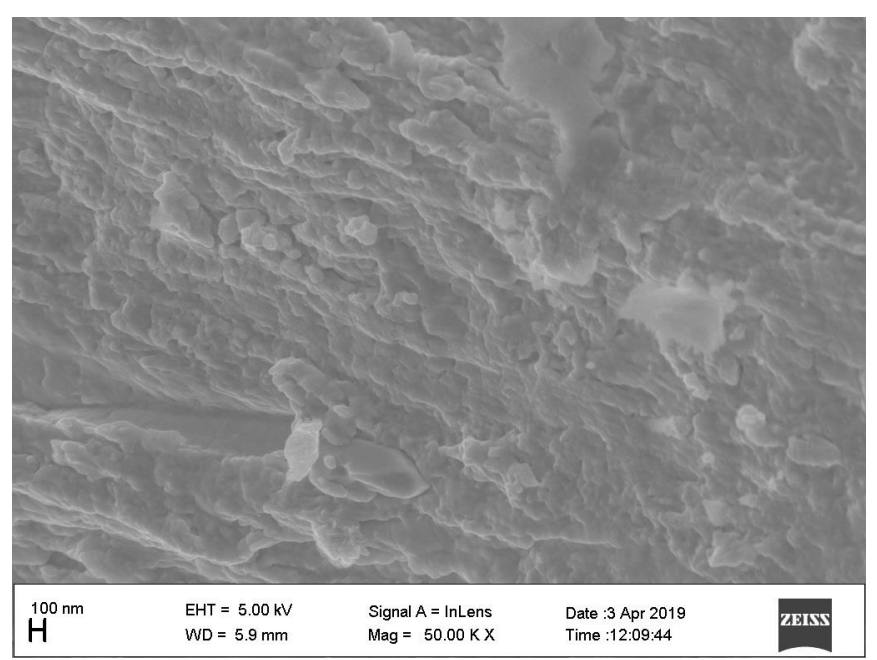

Fig. 4. Microstructures of the alloy at 50K X.

\section{References}

1. J. Koo, J. Chang, Y. W. Lee, S. J. Hong, H. M. Lee. J. Alloys Compd. 608, 126 (2014). Crossref

2. M.M. Salleh, A.M. Bakri, M. Zan, F. Somidin, N. F. M. Alui, Z. A. Ahmad. Mater. Sci. Eng. A. 556, 633 (2012). Crossref

3. A. K. Gain, L. Zhang, J. Mater. Sci. Mater. Electron. 27 (1), 781 (2016). Crossref

4. H. Wang, S.-B. Xue. Sci. Mater. Electron. 27 (1), 1 (2016). Crossref

5. F. Gnecco, E. Ricci, S. Amore, D. Giuranno, G. Borzone, G. Zanicchi, R. Novakovic. Int. J. Adhes. Adhes. 27 (5), 409 (2007). Crossref

6. A. K. Gain, Y.C. Chan, W. K. C. Yung. Mater. Sci. Eng. B. 162 (2), 92 (2009). Crossref

7. S. Y. Chang, C. C. Jain, T. H. Chuang, L. P. Feng, L. C. Tsao. Mater. Des. 32 (10), 4720 (2011). Crossref

8. J. C. Leong, L. C. Tsao, C. J. Fang, C. P. Chu. J. Mater. Sci. Mater. Electron. 22 (9), 1443 (2011). Crossref

9. W. M. Chen, S. K. Kang, C. R. Kao. J. Alloys Compd. 520, 244 (2012). Crossref

10. T.H. Chuang, Y.T. Huang, L.C. Tsao, J. Electron. Mater. 30 (8), 945 (2001).

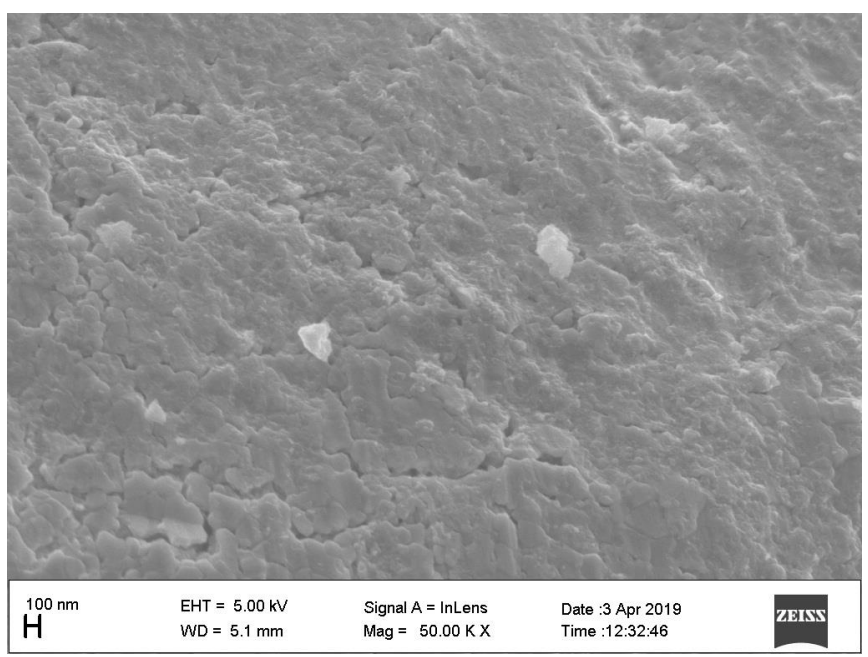

11. S. Cheng, C.-M. Huang, M. Pecht. Microelectronics Reliability. 75, 77 (2017). Crossref

12. K. Tu, H. Hsiao, C. Chen. Microelectronics Reliability. 53 (1), 2 (2013). Crossref

13. M. Schwartz. Soldering: Understanding the basics. First edition. USA, ASM International (2014) 184 p.

14. C. Handwerker, U. Kattner, K.W. Moon. Fundamental Properties of $\mathrm{Pb}$-Free Solder Alloys. In: Lead-Free Soldering (Ed by J.Bath). Boston, MA, Springer (2007) pp. 21-74. Crossref

15. C. M. L. Wu, C. Q. Yu, C. M. T. Law, L. Wang. J. Mater. Res. 17 (12), 3146 (2002). Crossref

16. X. Xu, A.S. Gurav, P.M. Lessner, C.A. Randall. IEEE Trans. Ind. Electron. 58 (7), 2636 (2011). Crossref

17. X. L. Zhong, M. Gupta. J. Phys. D. Appl. Phys. 41 (9), 095403 (2008). Crossref

18. A. K. Gain, L. Zhang, Y.C. Chan, J. Mater. Sci. Mater. Electron. 26 (9), 7039 (2015). $\underline{\text { Crossref }}$

19. L. C. Tsao, C. H. Huang, C. H. Chung, R. S. Chen. Mater. Sci. Eng. A. 545, 194 (2012). Crossref

20. L. Zhang, K. N. Tu. Mater. Sci.Eng. R. 82, 1 (2014). Crossref

21. A.K. Gain, Y.C. Chan, W.K. C. Yung. Microelectron. Reliab. 51 (5), 975 (2011). $\underline{\text { Crossref }}$ 